\title{
The "Mystery" of Innovation: Bridging the Economic and Business Thinking and the Stra.Tech.Man
}

\section{Approach}

\author{
Charalambos Vlados \\ Department of Economics, Democritus University of Thrace, Greece \\ School of Business, University of Nicosia, Cyprus \\ E-mail: vlad.coop@gmail.com
}

Fotios Katimertzopoulos (Corresponding author)

Department of Economics, Democritus University of Thrace, Greece

E-mail: fkatimertzopoulos@gmail.com

Received: January 23, 2019 Accepted: February 9, 2019 Published: March 4, 2019

doi:10.5296/ber.v9i1.14452

URL: https://doi.org/10.5296/ber.v9i1.14452

\begin{abstract}
This study examines the concept of Innovation from two different conceptual and theoretical prisms: the science of economics and the theoretical tradition of entrepreneurship and organizational theory which both offer a remarkable distance in the way in which innovation is perceived. This study supports the notion that, by pointing a theoretical focus based on a co-evolutionary approach, centered on the "evolutionary heart" of the capitalist business, modern economic science and business thinking will gain from bridging the study of the innovative phenomenon with analytical fertility. To achieve this, the physiological structure and organic evolution of Strategy-Technology-Management (Stra.Tech.Man) synthesis of business becomes the center of attention, perceiving ultimately the firm as an active actor and even as a major structural co-creator of the sectors of industries and the socio-economic systems which is hosted in.
\end{abstract}

Keywords: Stra.Tech.Man innovation, Innovation economics, Organizational innovation, Strategy innovation, Economic development, Business development 


\section{Introduction and Positioning of the Problematic: Searching for a Synthetic Definition of Innovation}

The interest regarding the problematic of innovation was not born recently. Sir Francis Bacon first presented the work of New Atlantis, where he describes a technological paradise, to which honours are attributed to the inventors, honours which would, of course, be classified in this "utopia" depending on the importance of the invention (Weinberger, 1976).

In recent years, the topic of innovation is becoming the most essential and decisive -directly or indirectly- in any attempt to interpret and predict the common socio-economic future (Aghion \& Howitt, 1997; Boyer \& Didier, 1998; Fagerberg, Fosaas, \& Sapprasert, 2012; OECD, 2014a; OECD, 2014b; Cerne, Jaklic, \& Skerlavaj, 2016). The structural foundations of socio-economic reality, technological evolution as well as all associated changes and transformations into the contained and evolving socio-economic affairs can only take place, constantly, through the implementation of innovations, of every kind, level and range (Acemoglu \& Robinson, 2012; Brynjolfsson \& Mc Afee, 2015; Gordon, 2016). The ability of a society to innovate constitutes the fundamental mechanism for its renewal and overall evolution, and ultimately it involves every aspect of the economic and social development process in which the society participates (Aghion et al., 2005; OCDE, 2016).

Undoubtedly, innovation never enters the world unimpeded and in a "peaceful" way: It always requires multiple incisions and rupture in its implementation and assimilation. Its core lies in the sustained interplay between creativity, dynamic adaptability and the synthesis of strategic, technological and managerial skills, people, groups and organizations (Carlino \& Kerr, 2015; Vlados \& Katimertzopoulos, 2018).

And yet, in overall terms, the concept of innovation continues to be covered by an atmosphere of "mystery": Ambiguity, equivocation, relative conceptual fluidity and fragmentation. The purpose of this article is to attempt to elucidate this issue striving to introduce a synthetic conceptual counterproposal, which will bridge a first conditional expression of economic and business thinking on the dynamics of innovation.

\section{Methodology and Organization of the Present Problematic}

The discussion that follows a brief and comprehensive review of the literature with the following succession:

- The presentation of the main conceptual outline in modern understanding of innovation, focusing on the observed multiplicity in the examination of the innovation phenomenon and attempting to formulate an introductory functional definition of innovation.

- The critical examination of the central different viewpoints of innovation and the related conceptual transformation within the Economic Science.

- The critical examination of the central different viewpoints of innovation and the related conceptual evolution within the Business and Organisational Science.

- The attempt to synthesize a unified concept of innovation, through the creation of an 
analytical bridge between Economic and Business science, in combination and through the evolutionary terms of Strategy-Technology-Management (Stra.Tech.Man) (Vlados \& Katimertzopoulos, 2018).

\section{The Main Conceptual Framework of Innovation}

\subsection{The Multiplicity in the Approach of the Innovative Phenomenon}

As it has been rightly pointed out by Wolfe (1994), the most obvious element that can be found in the literature of innovation is that its research results are very vague. Even in terms of providing a simple definition or thematic "retrenchment" of the subject of innovation, things are far from being clear. In practice, there is a multiplicity of different, largely convergent and complementary definitions and viewpoints to innovation, being at the same time, however, opposing and mutually exclusive to each other. In reality, there are many perspectives, different interpretative priorities and multiple focal points (Dasgupta \& David, 1994; Freeman \& Soete, 1997; Guillaume, 1998; Clément \& Lelarge, 2006; Wolfe, Wright, \& Smart, 2006; Damanpour, 2016).

A large number of theorists have tried to capture and attribute, in recent decades, the content of the "mystery" of innovation, each one in its own way. Among the most fruitful definition efforts, Porter (1990) considers innovation as the determining factor in defining industrial structures, as the absolute strategic priority of all businesses, and as a one-way street to gain the competitive advantage (Porter \& Heppelmann, 2014; Porter \& Heppelmann, 2015). For Narayanan (2000), innovation must be perceived primarily as a production process, since innovation refers to both output and process through which a technologically feasible solution to a problem can be achieved, that has arisen either because of a technological opportunity or a consumer need (Narayanan \& O'Connor, 2010).

According to Deakins \& Freel (2007), in an entrepreneurship approach, the concept of innovation refers to substantial changes in the technological background of products or production processes. According of Crossan \& Apaydin (2009) innovation is the production or adoption, assimilation and exploitation of a value-added innovation in the social and economic spheres; the expansion and renewal of services, products and markets; the development of new production methods; and the establishment of new management systems: Here innovation is perceived, simultaneously, both as a process and as a result.

Thus, it seems that a very broad pluralism of definitions of innovation and a constant multiperspectivity exists among researchers and analysts. Theorists seem to understand the concept of innovation either from the strategic viewpoint or from the technological point of view, and sometimes even from the general administrative approach.

\subsection{Towards a Functional Definition of Innovation}

Attempting a first open synthesis with simple functional terms, innovation can be seen, ultimately, as the application of new ways of solutions on older or new problems: that is, more efficient, more effective and more "profitable" ways in a broader sense of these terms. Naturally, this definition is also incapable of claiming the meaningful integration - and let 
alone exclusivity - of the innovation reality.

In this open orientation it could be said that innovation is a new applied concept, a new "construction" (in a broader sense) or a new method that manages to improve the performance of any "mechanism" in anything. The minimum requirement for an innovation is either the product or the process or method to be able to be classified as new (or significantly improved), increasing ultimately the performance of the carried organisation.

In overall terms, however, there seems to be a remarkable distance in the way in which innovation is perceived on the one hand by Economic science and on the other by the theoretical tradition of Entrepreneurship and Organisational theory. Each overall perspective, within the dominant paradigm that governs each period (but also on the fringes of the dominant approaches in the context of "heterodox" approaches that emerge) seems to hold on to the concept of innovation a different handling and a different interpretive architecture (Kuhn, 2012; Godin, 2015). This conceptual distance, indeed, seems to be useful in trying to be resynthesized conceptually by liberating the overall explanatory potential of the concept of innovation.

\section{The Economic Thinking in the Study of the Innovation Dynamics}

\subsection{Fertility of Classical Political Economy and the "myopia" of Neoclassical Tradition and Conventional Keynesianism}

Certainly, the foundation of the entire building of economic science lays on the Classic Political Economy (CPE). In fact, the first roots of the Economic Development Theory can be found in the work of classical economists of the 18th and 19th centuries (Screpanti \& Zamagni, 2005; Blaug, 2008; Skousen, 2008).

Overall, in the work of A. Smith (The Wealth of Nations in 2000), the concept of innovation even without an explicit reference - emerges as the deepest explanatory foundation of the entire development process. It is not interpreted strictly on the mechanical-technological basis of innovation (new machines), but is opened directly - and with great overlap - to its fully interconnected management content (expanded division of labor) and its necessary broader strategic horizon (international trade and conquest new markets).

The thought process of Smith (2000) is, undoubtedly, the birth mother of the Economics of Innovation as it realizes the expansive dynamics of the "new" at all levels as the fundamental mechanism of capitalist development itself (Figure 1). 


\section{Macrothink}

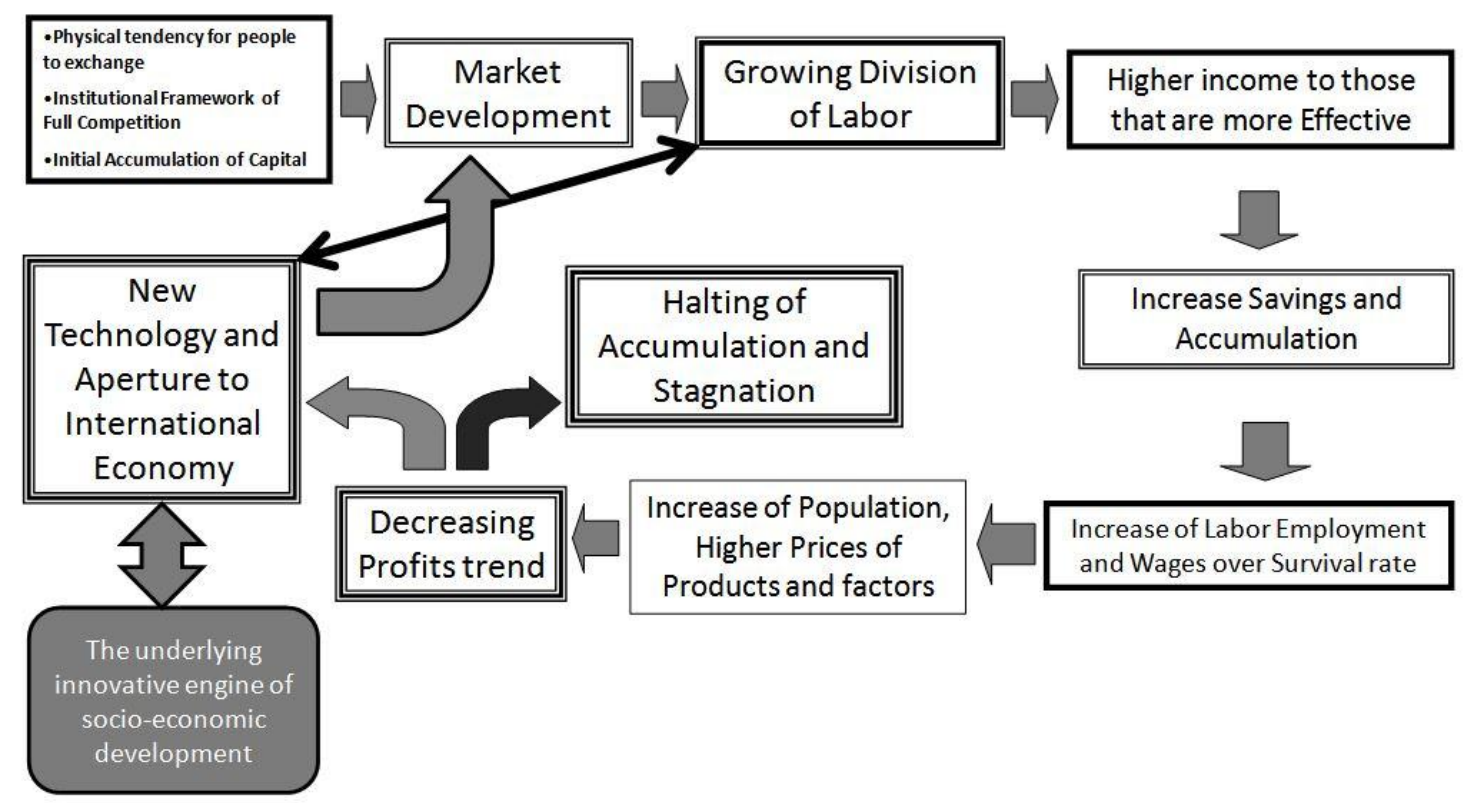

Figure 1. The underlying engine of innovation and the overall model of capitalist development in accordance with the thought of A. Smith

The first decades between the publication of The Wealth of the Nations of Adam Smith (2000) and the Principles of David Ricardo (2002) were undoubtedly a period of excitement and euphoria for the bourgeoisie of the time, in the context of the emerging and constantly empowering industrial revolution (Mark, 1993).

In general, however, the classical political economy over the years seems to have turned towards less optimistic projections (Dienstag, 2006). But particularly Thomas Robert Malthus, through his work and the "Essay on the Principle of Population", argued that reality was more conducive to the necessity of assimilating the principles of moral self-restraint and puritanism than to the optimistic prospect of an unimpeded innovation towards future improvements of human societies (Slaboch, 2018).

Obviously, in the forefront of criticism against capitalist optimism in the 19th century is the contribution of Marx. Marx, principally in Capital, but also throughout his rich work, fully accepts, deepens and reinforces, on a theoretical level, the pre-existing classical position that expansive internationalization is an absolutely necessary condition for the existence of capitalism itself. At the same time, Marx together with Engels in the Manifesto of the Communist Party, did not hesitate to recognize the revolutionary developmental role of the bourgeois / capitalist class itself and of the technological progress that mobilizes and expresses in "deterministic" terms. In Marx's theoretical perspective, in particular, the production conditions are the main determinants of the overall and surrounding social structure, which in turn creates values, lifestyles, cultures and institutions (superstructure), which ultimately set the limits of development of the economic base. These forms of production and the accompanied social constructs have their own co-evolutionary logic. According to Marx's perspective, the deeper center of the developmental motor of capitalism -in other words, the identification of the historical specific productive forces - recognizes the 
dynamic evolution of the means of production and the tools of each place and time. In this way, the overall technological development becomes, ultimately, in his view, the ultimate protagonist of the socio-economic development (Marx, 1955; Marx, 1976; Castoriades, 1987; Hobsbawn, 2017), (Figure 2).

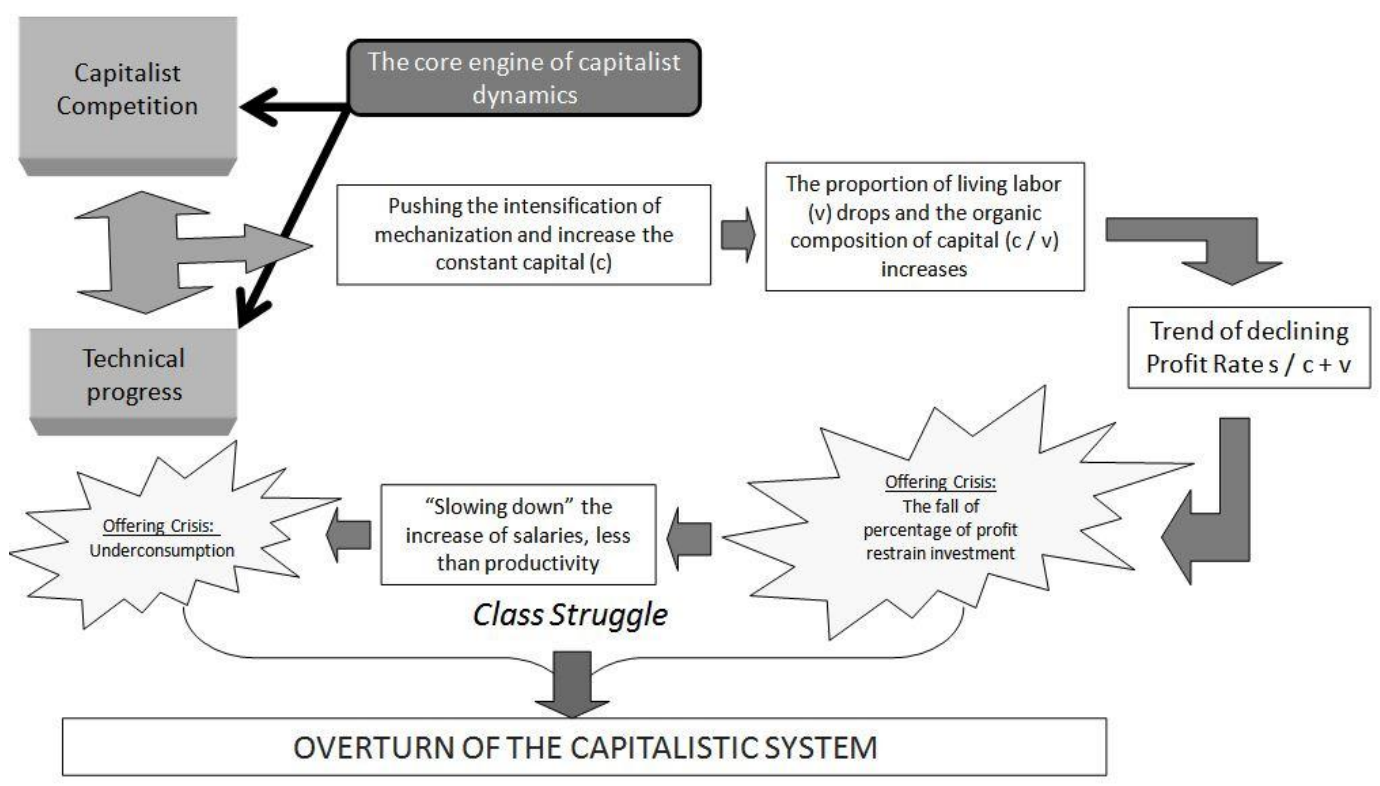

Figure 2. The "relentless" dynamics of technical progress and competition and the inevitable collapse of capitalism

Later on, the arrival and prevalence of the Paradigm of Neoclassical Theory seemed to throw an interpretative shadow upon the subject of innovation dynamics in the socio-economic terms. The traditional "conventional" economic theory, the neoclassical as well as the theories inspired and directed by orthodox Keynsianism, were never really "charmed" with the overall innovation problem (Weintraub, 2007).

To start with, the conventional neoclassical theory of growth, in particular, considers the operation of the market as a simple- and in essence disconnected from any wider socioeconomic system - resource allocation mechanism, in which the demand interacts with the supply, in order to determine the prices, achieve and maintain market balance (Parkin, 1997). The capitalist business is therefore considered here in the vast majority of the theoretical operations to be a "hollow cover", a static "black box" which exists to solely perform an automatic transformation of economic inputs into outflows. In neoclassical theory, in particular, the pace of technological change affects "mysteriously" the rate of economic growth without being however affected by it. As such, the reverse is not applied: The relationship appears strictly as to be as a one-way direction. According to this theory, innovation is always caused by a variety of independent exogenous variables and mechanisms, and as such, actors operating with consistent logical action criteria can control it to some extent but cannot influence the rhythm and its direction (Fonseca, 2002; Geels, 2005; Cerne, et al., 2016).

Paradoxically, even in its deeper sense, traditional economic theory finds it difficult to see 
clearly and to "assimilate" the dimensions new knowledge and innovation of this interpretation. According to Marshall (1890) the Capital consists largely of knowledge and organization, is the most powerful production mechanism and the organization helps knowledge. However, for neo-classical economists, the key issue was the use of the existing knowledge, which is concentrated only on price information. They did not concern how this knowledge is created and neglected to examine the position of the business as a creator of knowledge. On the contrary, the Austrian School of Economics, represented mainly by Friedrich von Hagen and Joseph A. Schumpeter, gave more importance to the role played by knowledge in economic affairs (Hayek, 1941; Schumpeter, 1949).

However, the fundamental Keynesian tradition does not appear to be more open-minded in interpreting terms regarding the study of the innovation dynamics. Despite the very clear deviation from the neoclassical perspective - especially regarding the possibility of achieving automatically full employment balance- it also seems unable to welcome the problematic of innovation in a fuller and structurally more fundamental way (Keynes, 2001).

In his General Theory, Keynes (2001) under a different approach neglected the issue of investments which aim to introduce faster and more efficient new technologies. As Freeman \& Soete (1994) quite rightly point out, in fact, in General Theory, Keys was retreated to positions that ignore the overall term of technology by introducing the largely artificial concept of a temporary fall in the marginal profitability of capital, without correlating with the real changes in technology and capital stocks. For the Keynesians, therefore, the importance to determine the nature of new technologies and fast-growing industries was structurally insignificant.

\subsection{The Drastic Reintegration of Innovation Dynamics into Modern Economic Theory}

Undoubtedly, J.A. Schumpeter (1883-1950) provided the most fundamental contribution to the exploration of the nature and dynamics of innovation, opening a whole new way of interpreting the scholarly economic science. In comparison, for J.A. Schumpeter's innovation process was, by its very nature, a structural cause of imbalance and development in the system, and not the manifestation of a calm and smooth transformation into a new market balance (Schumpeter, 1949; Schumpeter, 1951; Scherer, 1984).

In this context, indeed, the fundamental concept of "creative destruction" emerges: The creative destruction that is taking place according to its perspective, namely the progressive destruction and demolition of outdated technologies, the decadent sectors of economic activity, and the receding and dying reassured enterprises, and at the same time, new technologies of new branches of economic activity and innovative enterprises emergence through a evolutionary mimetic process aimed at monopoly returns on innovation (Schumpeter, 1942).

Therefore, these theoretical bases articulate an attempt to understand the concept of innovation in an evolutionary and structural way and the process by which it develops and diffuses into the individual socio-economic systems and the global system. What seems to be of increasing importance is the role of institutional dimensions and the way they interact in 
creating new knowledge (Brynjolfsson \& Mc Afee, 2015; Gordon, 2016). The systematization of this overall institutional dynamics that causes -and its being provokedfrom innovation has been developed within the thematic national innovation systems (OECD 1997; Bassis \& Armellini, 2018).

There are a variety of definitions that attempt to approach the issue in a convergent and complementary way. According to them, a national innovation system can be characterized as:

- The national institutions, the incentive structures and the competitive advantages that govern them and which determine the degree and direction of technological learning within a country (Patel \& Pavitt, 1994).

- That distinct sum of institutions that jointly and personally contribute to the development and diffusion of new technologies and provide the framework within which governments shape and implement policies to influence the innovation process. It is, therefore, a system of interconnected institutions for the creation, storage and transfer of knowledge, skills and artifacts that define new technologies (Metcalfe \& Georghiou, 1997).

Most of the above dimensions have been studied, analyzed and synthesized within the framework of the French "School of Regulation" since the 1970s (Aglietta \& Orléan, 1982; Billaudot, 1996; Billaudot, 2001; Boyer, 2004; Amable, 2005). In a parallel conceptual direction, already since the late 1980s, the approaches of "micro-competitiveness" were also emerged. In this stream of discussion during the late 1980s, the "micro-orientation" in the MIT approach was also recorded (Dertouzos, Lester, \& Solow, 1989). In this, a "bottom-up" approach is usually chosen instead of the usual "top-down" of competitiveness including, indirectly but absolutely decisively, the innovation process. In these approaches, a point of convergence is the finding that knowledge and organization of relationships, both inside the enterprise and between enterprises, in a comparable historical and spatial socio-economic context, is always of great importance.

On this conceptual basis, the concept of "innovation environment" (milieu innovateur) is also built (Aydalot, 1984; Aydalot, 1986a). Specifically, an innovation environment can be defined as a set of multi-dimensional diverse business activities and diffusion of knowledge which is open to the exterior and incorporates, in a gradual process, expertise, rules and "relational capital» (capital relationnel). Particularly, under this approach, spatial development is perceived as a synthetic product of both innovative processes and socio-economic synergies, which fan out into specific spatial contexts, of local range.

By this reasoning, local innovation system is defined and localized at a lower level of spatial perception of the innovative environment; the structural components of which can be grouped into three main categories: a) the running skill, b) the operational rules, c) the relational capital, namely: capital in terms of the value of the generated, maintained and reproduced relationships.

In a converging direction, Carlota Perez's "Neo-Schumpeterian" work is also being driven. The most interesting point in Carlota Perez's reasoning in relation to the "change of 


\section{NI Macrothink}

Business and Economic Research

ISSN 2162-4860

2019, Vol. 9, No. 1

techno-economic paradigm " is the view that the periods of high growth explosions occur only when there is a "good combination", an active agreement between the new techno-economical " paradigm " of a long wave of economic development and the social and institutional climate that surrounds it (Perez, 1983; Perez, 2013; Marin, Navas-Aleman, \& Perez, 2015).

\subsection{Innovative Dynamics, Socio-economic Systems and Globalization}

In this context, however, a series of very important issues are still open: Can the logic of globalization be combined with this historically and institutionally determined innovation momentum, which is always perceived as the childbirth of specific spatial socioeconomic systems? The innovational dynamic globalization will not, in the end, surpass the differences of socio-economic systems? Is not equating and ultimately "flattening" the differences between different socio-economic spaces? What significance can anymore find in any local or national particularity in terms of innovation (Amable, Barre, \& Boyer, 1997; OECD, 2014b; OECD, 2016; Katimertzopoulos \& Vlados, 2017).

Christopher Freeman explains in particular that: In contrast to the recent work on "globalization", this research argues that national and regional innovation systems remain a necessary field of economic analysis. Their importance is drawn from the networks of relationships that are essential for a business to innovate. Although external international connections are becoming, of course, increasingly important, the influence of the national education system, industrial relations, technical and scientific institutes, government policies, cultural traditions and many other national institutions are fundamental to understanding innovation. And he concludes that differences in national socio-economic structures continue to make a decisive contribution to competitive success even at the era of globalization (Freeman, 1995; Freeman, 2002; Edquist \& Hommen, 2008; Kuhn, 2012; Paunov, 2012; Bremmer, 2014), (Figure 3).

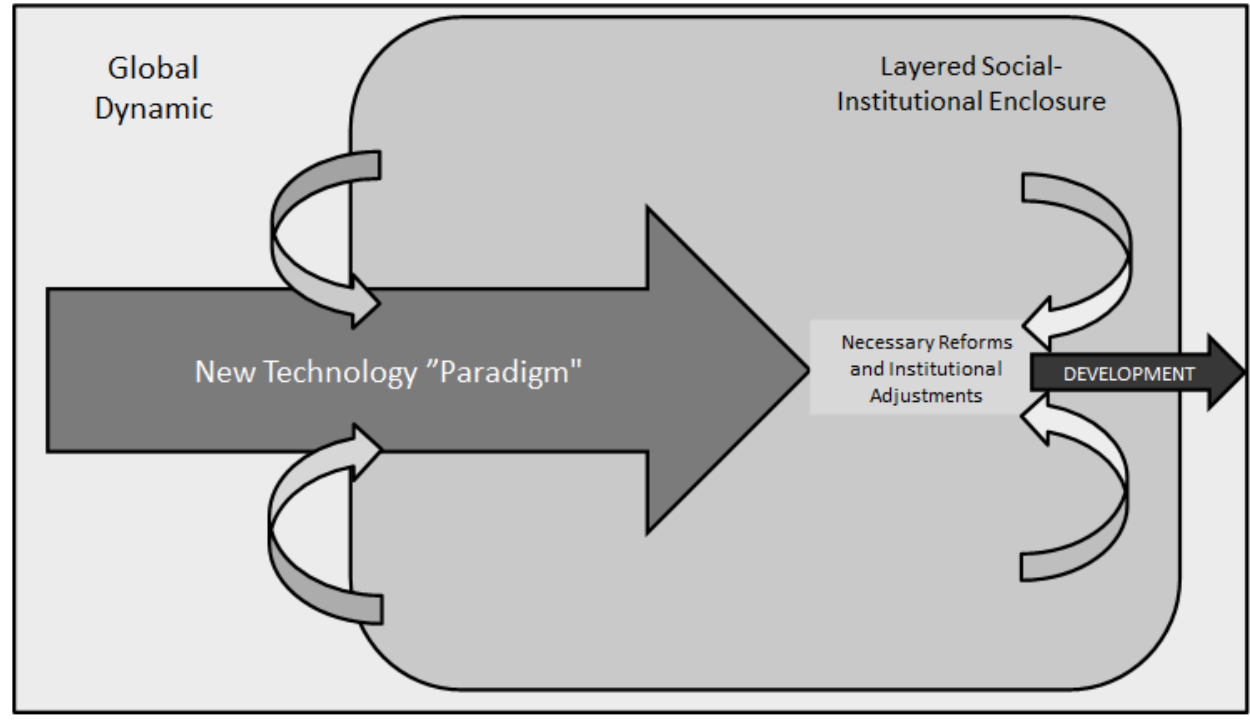

Figure 3. Changing the techno-economic paradigm and the necessary institutional adjustments 
And indeed Freeman's point seems to bring his ideas closer to the conclusions of Michael Porter, who starts from a clearly different theoretical starting point. In particular, Porter (1990), in his many contributions to economic and strategic theory, has also introduced an analysis of the so-called national "diamond" of competitiveness. The analysis of M. Porter's "diamond" attempts, in particular, to interpret the national advantage enjoyed by some national industries and businesses within them (Porter, 1990). In the depth of his analysis, the dimension of the inner innovation dynamic of the national system emerges indirectly.

The focus of Porter's analysis is therefore on the comprehensive exploration of the construction of sectoral competitiveness, approached by its national contexts. This analysis leads to the conclusion that the competitive advantages are not static, not "inherited forever" and do not arise automatically, never and nowhere. Instead, they are created and recreated, always, through peculiarities that vary from country to country and from sector to sector (Porter, 1990).

However, in subsequent years, M. Porter has repeatedly stressed the importance of localitythe "home advantage" that acquires great importance in the globalization (Gibson, 1998). In his reasoning, "innovation advantages" are always subject to an inevitable process in progress, in which the technology eliminates the traditional advantages of location. But by doing so, it can create new advantages for the location, possibly at a higher level.

All in all, approaches that attach specific interest to the spatial- institutional and historicalbackground of the innovation process seem extremely useful in understanding the modern global dynamics of innovation. The nation-states and the socio-economic systems that they are formed within them, at every level (local, regional, national and international) are still instrumental in shaping the overall innovation dynamics (Hanson, Lind, \& Muendler, 2015; Chaney, 2016; Katimertzopoulos \& Vlados, 2017; Arkolakis et al., 2018).

\section{The Critical Points of Business Thinking in Studying Innovation Dynamics}

\subsection{The Foundations and Contemporary Transformation in the Perception of Innovation in Business and Organizational Thinking}

Beyond Economic thinking and science, the innovative and cognitive phenomenon has, certainly, been intensively studied by the wider Organizational and Business Science (Nonaka \& Konno, 1998; Prax, 2007; Walker, Chen, \& Aravind, 2015). In this context, interpretive efforts usually have been focused on individual "game players", businesses and organizations by studying them at all their activity levels. Some of them are focused on the overall organizational level, some others on the segmental, the departmental or the team; others even on the individual-psychological. Few others attach great importance to their strategic priorities, to the technological parameters, or finally to the management requirements of the innovation process. We see here, no doubt, a rich variety of multiple interpretations.

First of all, for Peter Drucker, the pioneer in examining innovation in management science, innovation is simply the response to change in a creative way: It is the process of producing new ideas, the improvement of processes or the redesign of products and services - and at another level, more abstract, innovation is the new way of thinking in a business (Edersheim, 
2007).

In addition to fundamental approaches, in the last two decades, in particular, a new stream of thought in organizational science has been remarkably enhanced, calling for a radically new perspective. Apart from the fundamental approaches, in the past two decades in particular, a new current of thought in organizational science that calls for a radically new optic has strengthened noticeably: The perception and study of social organizations in terms of living organisms and ecosystems (Kashan \& Mohannak, 2017; Bassis \& Armellini, 2018). This approach calls for a definitive transition from "engineering" to "biology" of businesses, providing a vital opening for bridging the gap with the perspective of modern economic science, as we will see later (Kauffman, 1993).

Beyond this significant trend - with a deeper character of a paradigm transition - in the last decades there is also a remarkable - even if relatively subtle - analytical tripolism regarding to the understanding of innovation dynamics in the international business literature, which will be briefly examine here (Clarke \& Clegg, 2000; Dogan, 2001; Antonelli, 2003).

\subsection{Approaches of Innovation that Grand Strategy its Analytical Priority}

First, Michael E. Porter in this particular analytical orientation - in an indirect but remarkably compliance with the views of Hammel and Prahalland - distinguishes the failure of management to tell the difference between strategic and operational-managerial efficiency as the main aspect of the problem: While both dimensions are essential for leading performance of an organization, their significance may vary (Porter, 1996; Eisenhardt \& Martin, 2000; Grant \& Baden-Fuller, 2004; Hamel, 2006; Zhou \& Sun, 2016).

Porter notes, in particular, that the only valid and lasting way to achieve a competitive advantage is through innovations and substantial strategic repositioning (Porter, 1996). Naturally, these innovations and reorientations in their perspectives must always be consistent with a consequent and original strategic direction. That is why there must be an inaugural and fundamental strategic vision within which the innovations that are underway will operate (Note 1).

In turn, Prahalad promotes the modern strategic innovation challenge to the world of co-creation, through the direct and continuous cooperation between producer and user, underlining that while the strategic orientation (or strategic intent) of an business may be obvious, strategy is always a process of continuous experimentation, risk reduction, time compression and investment minimization and, at the same time, maximization of the market impact. As such, strategy must be primarily and always a process of innovation and discovery (Prahalad, 2004).

In the same direction there are many other newer approaches that bring forward the motion of searching the best strategic ideas outside the traditional boundaries of an organization. Whether reference is made to open invitation to raise external resources (crowdsourcing) of Howe (2009), either in cooperative economy (wikinomics) of Tapscott \& Williams (2010), or collaborative thinking (we-think) of Leadbeater (2009), in all these converging perspectives, it is now clear that the modern innovative game requires the generous abolition of the 
watertight boundaries of business and its drastic opening to their strategic external environment.

In the same direction, already since the 1990s, Norman Augustine, when referring to change, sectoral reconstruction and survival, he began by pointing out that all modern businesses are finding themselves in a highly uncertain and fluid competitive environment. His conclusion was that in an increasingly fluid environment of continuous restructuring of sectors, only two types of companies are traced: a) those who change and survive and b) those that end up ceasing its operations (Augustine, 1997).

In this line of thought, Kim \& Mauborgne (2005) gave a quite original answer to whether and how a business can escape from the direct competitive confrontation, and survival beyond the painful and "bloody" path between hammer and the anvil. They argued in particular that the most dynamic businesses of the future would not climb "fighting" with their competitors in already existing and incumbent industries, but they will do that by creating new "blue oceans", e.g. new, unspoiled areas, new sectoral fields, which are offered for rapid and "bloodless" growth.

The strategy of these pioneering analysts is based on what they call 'value innovations', e.g. the creation of a completely new, distinct proposal-value for their customers, thus leaving behind their traditional sectoral rivals and creating a whole new demand (Markides \& Geroski, 2004; Crainer \& Dearlove, 2005; Markides, 2008) (Note 2 \& Note 3).

\subsection{The Innovation Approaches that Attribute Analytical Prominence to Technology}

At the same time, a large number of analytical contributions to the problem of innovation, in our days, attribute a prominent and overwhelming importance to the technological dimension of innovation (Boonstra \& Vink, 1996; Uchupalanan, 2000; Schilling, 2008; Guellec \& Paunov, 2017).

In this direction, particularly important is Christensen's approach with his research Disruptive Technologies: Catching the Wave (Christensen \& Boyer, 1995). In his perspective, disruptive innovation - subversive and even divisive innovation - establishes a theoretical model of explanation of the rapid technological changes that develop, diffuse and interfere with business activity on a global level (Christensen \& Boyer, 1995). Specifically, Christensen argues that the disruptive technologies follow performance trajectories, and in particular during in their first steps, they are considered marginal and "heretical." Disruptive innovation is defined as a product or service designed for a new customer group characterized by uncertainty and instability in its early stages (Christensen, Dillon, \& Hall, 2016).

Christensen's approach, over the time, has received a variety of criticism. First of all to it is worth highlighting that the act of change, which inevitably introduces an innovation, always refers more to the sphere of overall socio-economic dynamics than to narrowly meant technology. Something that seems to be underestimated by some technologists like Christensen is the fact that there is always a necessary structural period for the understanding and socio-economic assimilation of change. Moreover, the theory of subversive innovation has often received criticism as, in addition to being seen several times as a supposed 
"lifesaver" or as the sole pursuit of a business, is an approach that is based on selected case studies perceived as the main proof of element and therefore it cannot be interpreted as a theory that can explain all aspects of modern economic life (Krugman, 2014; Lepore, 2014; Weeks, 2015; Guellec \& Paunov, 2017) (Note 4).

Deeper than Christensen's approach, it is becoming clear that only when people, and the groups in which they are involved, feel more confident and certainty in experimenting, then they pursue more new ideas and practices.

\subsection{Innovation Approaches that Attribute Analytical Priority to Management}

Appearing as a third pole to the study of innovation dynamics within organizational and operational theory, the one that attributes the interpretive primary to the dimension of management emerges. Inside this perspective, there are a number of individual management approaches to the innovation process: from inspired leadership to systematic human resource management and from the proposal of total "reengineering" to the priority of effective management of intellectual capital of organizations (Birkinshaw, Hamel, \& Mol, 2008; Damanpour, 2010; Walker, Damanpour, \& Devece, 2011; Volberda, Van Den Bosch, \& Mihalache, 2014).

Naturally, this analytical line is not late. For example, since the 90s, Belasco \& Stayer (1994) concluded that what is important for the innovative performance of an organization is primarily the actions of its leader, having the principal responsibility to oversee that the people to whom has delegated responsibilities focus on the "right" objectives: The hard strategic question of "what am I doing ?", they conclude, is meaningless if the nature of what the customer values remains unclear; consequently, it will be impossible to offer it consistently. Ultimately, the innovative efforts of a business must, according to this approach, always focus on solving the specific needs of the customer, which clearly implies a necessary opening of the organization's management logic to the requirements of their socio-economic environment.

Certainly, the approach that has excelled the previous in this particular problematic is the one of Business Process Reengineering (without of course avoiding criticism). Specifically, based on Hammer and Champy's perspective, redesigning business processes eventually changes almost everything within an organization, as all aspects (employees, jobs, managers and values) are linked to each other. The authors note in particular that the characteristics required by the post-industrial era are, on the one hand, orientation towards innovation, change and personal responsibility, and on the other hand, the cooperation of the groups, a degree of unselfishness under which the client becomes the center of the processes and actual capacities, especially learning, so that complex work tasks can be carried out (Hammer \& Champy, 1993).

On the other hand, Kanter (2009) focuses on the leadership's innovative capability and estimates that the best leaders have some, almost universal features: They are much more effective when they can build coalitions, develop and use a support system, to encourage, to listen, elements that strengthen the innovation capacity of each organization. 
In a similar direction, Warren Bennis believes the biggest challenge for leaders in the 21st century will be how to unleash the mental power of their organizations. He concludes that the problem that almost all leaders will face in the future will be on how to develop the social architecture of their organizations so that it actually produces intellectual capital (Bennis, 2009; Bennis \& Goldsmith, 2010).

Comprehensively, the analytic focus to the human factor appears to be of particular interest in the study of the innovation phenomenon, in the context of modern organizational theory. In this direction, Sumantra Ghoshal also emphasizes in his work that financial capital is no longer a scarce resource. It therefore distinguishes the emergence of a different leadership philosophy that will dominate in the future, focusing on purpose, process, human philosophy and which will determine the innovativeness of organizations (Ghoshal \& Bartlett, 1999; Bartlett \& Ghoshal, 2002).

And what supplies are needed for a company to succeed tomorrow? At the same time, Ridderstråle \& Wilcox (2009) underline the need for modern innovative companies to come into contact with the feelings of their people (Note 5).

\section{Constructing the Bridge between Economic and Business Thinking on Innovation}

Observing the unfolding of the scientific literature of the last decades in the study of innovative dynamics, this paper arrives to the following three main constatation:

(1) In its evolution, modern economic science seems to be progressively turning towards an increasingly integrated systemic, evolutionary and institutional perspective on the concept of innovation (Arena \& Lazaric, 2003). Conceptual and interpretative constraints and analytical myopia of "traditional" economic- convective mainstream neoclassical and Keynesian direction - appear to be phasing out, to the extent that a fuller and more credible perception of the dynamics of innovation that drives contemporary socio-economic systems is becoming increasingly global (Veltz, 2000; White, 2002). Thus, it can be assumed that modern economic thinking seems to understand in an increasingly spherical way the importance of the socio-economic substratum of innovation and attribute to its study an increasing importance (Maurice \& Sorge, 2000). Nevertheless, economic science still seems, to a large extent today, hesitant to deepen its studies in profound business terms. In fact, seeing the problem in depth, "what is the capitalist business" is not - and never was - a question with unique and self-explanatory answers; something which does not seem to be fully perceived by a large portion of modern economists to whom traditional mechanical and simplistic perspective continues to dominate, although considerable theoretical progress has been achieved (Boyer \& Freyssenet, 2000; Durand, 2000).

(2) The progress in modern exploration of the innovation phenomenon in the organizational and business literature shows the gradual deepening of the study in all individual intra-organizational dimensions of the phenomenon, in a progressively more complete and penetrating way (Ahlstrom, 2010; Li, Y et al., 2010). Nevertheless, to a large extent, the necessary dynamic and cohesive perception of the socioeconomic environment of 


\section{Macrothink}

innovation continues to be perceived in a relatively partial and restrictive way (Lebas, 2003; Perez, 2003). At the same time, the preservation and reproduction of a specific "interpretive tripolism" is observed, with the rendering of the analytic primacy to either strategy or technology or management, while in contrast, it becomes progressively clear that the innovative phenomenon can only, always and necessarily, have a mixed and complex content, both in terms of strategy and in terms of technology and management (B $\lambda \alpha ́ \delta o s, ~ 2016$; Vlados \& Katimertzopoulos, 2018).

(3) The need for a more efficient articulation and synergy between the economic and business perspective on the innovation phenomenon seems progressively clearer, with the aim of a synergistic combination of the virtues of individual research traditions and methods, the mitigation of individualistic analytical "myopia", and ultimately the more complete and detailed perception of the subject of innovation itself, as it will be examined further in the study (Figure 4).

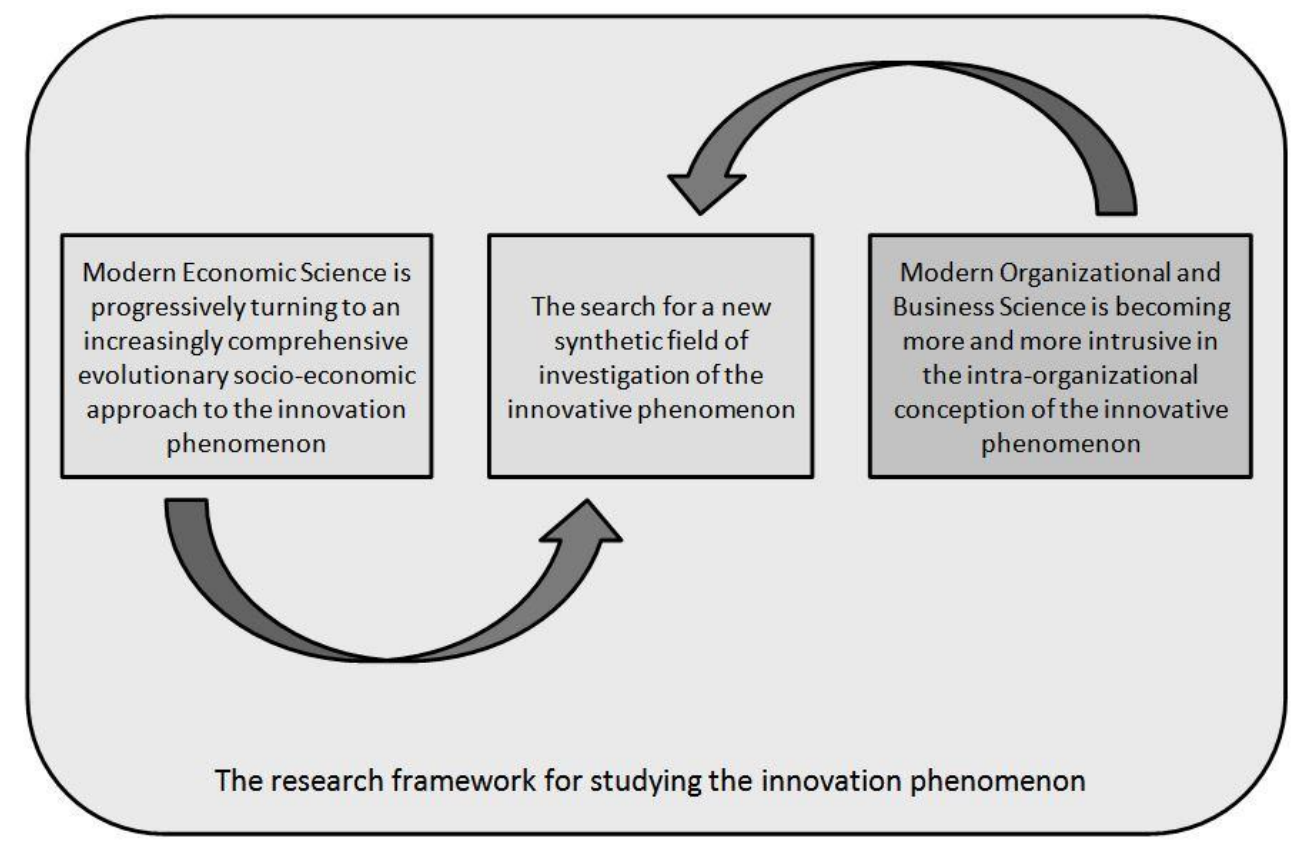

Figure 4. The attempt to bridge economic and business thinking on the study of the innovation phenomenon

In reality, innovation is always the birth of a complex synthesis of operational and socio-economic dynamics, which are always manifested in an indivisible co-evolutionary way (Figure 5). 


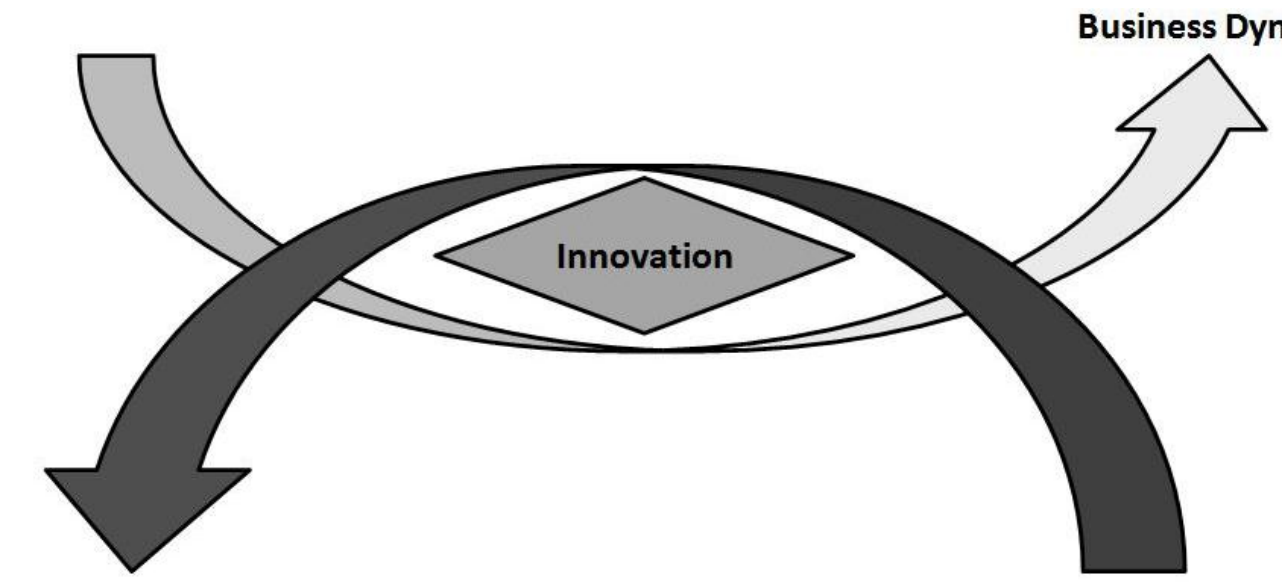

\section{Socioeconomic Dynamics}

Figure 5. Innovation as a synthesis of operational and socio-economic dynamics

Therefore, this study supports the notion that ultimately, modern economic and business thinking and science would have much to gain from a theoretical focus on this co-evolutionary basis, centered on the "evolutionary heart" of the capitalist business which, in return, could bridge an analytical fertility in economic and business thinking in the study of the multiphase innovative phenomenon (Rinkinen \& Harmaakorpi, 2018). In particular, this can be achieved by focusing on the physiological structure and organic evolution of the Stra.Tech.Man synthesis of the business (B $\lambda \alpha$ áos, 2016; Vlados \& Katimertzopoulos, 2018).

In this evolutionary approach, the Firm ceases to be considered merely as a passive acceptor of some exogenous changes and is, at last, perceived as one of the most critical - indeed, the most critical - producer of the profound changes that invade the socio-economic reality, at all levels, through the- incessant and imperative for its survival- innovative action.

In this orientation, the Firm is ultimately perceived as an active actor and even as a major structural co-creator of the sectors of industries and the socio-economic systems that is hosted in, in "living" ecosystem conditions (Rinkinen \& Harmaakorpi, 2018; Sako, 2018).

In this context of analysis, at least five critical questions pertaining to the evolutionary existence of the business are now at the center of exploring its innovative action (Figure 9):

(1) Who and how draws the path to the future (Strategy)?

(2) Who and how implements the function of acquiring, exploiting and using of information, knowledge and tools (Technology)?

(3) Who and how assumes the management of its activities, organization and coordination of production (Management)?

(4) Who and how conducts the composition of the above dimensions and the creation of innovation within (Synthesis of Strategy, Technology and Management Stra.Tech.Man)?

(5) Who and how guarantee the management of change and the assimilation of innovative 
actions within?

On this new analytical basis, ultimately, the innovative phenomenon can be approached as an indivisible and continuous synthesis of operational and socio-economic dynamics (Figure 6).

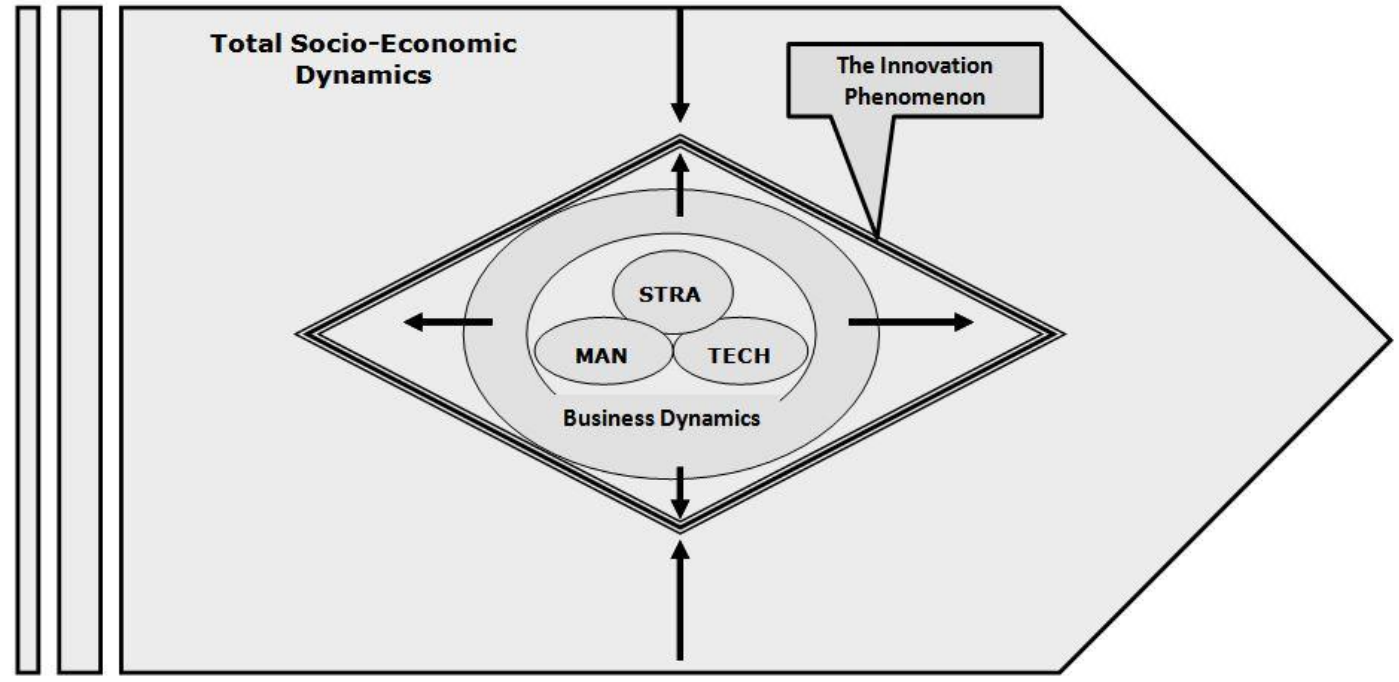

Figure 6. The Innovation Phenomenon as a synthesis between Operational and Socio-Economic Dynamics

\section{Central Conclusion}

According to the previous analysis, the present study concludes that the Stra.Tech.Man approach you propose has the potential to bilaterally overcome the conceptual barriers between the conceptual tradition of economic and business thinking: Since it perceives innovation as a dialectical product between the internal dynamics of enterprises organizations and, at the same time, the external dynamics of the socio - economic environment in which they operate and develop.

In this sense, the Stra.Tech.Man approach simultaneously enables a deepening of the economic perspective of innovation in terms of the political economy of the firm (Maurice \& Sorge, 2000; White, 2002) and the business vision of innovation into a direction of evolutionary approach to business development dynamics in fruitful combinational terms (Dosi \& Nelson, 1994; Boyer \& Freyssenet, 2000).

\section{References}

Acemoglu, D., \& Robinson, J. (2012). Why Nations Fail. The Origins of Power, Prosperity, and Poverty. New York: Crown.

Aghion, P., Bloom, N., Blundell, R., Griffith, R., \& Howitt, P. (2005). Competition and innovation: an inverted-u relationship. Quarterly Journal of Economics, 120(2), 701-728. https://doi.org/10.1093/qje/120.2.701

Aghion, P., \& Howitt, P. (1997). Endogenous Growth Theory. Cambridge, MA: The MIT Press. 
Aglietta, M., \& Orléan, A. (1982). La violence de la monnaie. Paris : PUF.

Ahlstrom, D. (2010). Innovation and growth: How business contributes to society. Academy of Management Perspective, 24(3), 10-23. https://doi.org/10.5465/amp.24.3.11

Amable, B., Barré, R., \& Boyer, R. (1997). Les Systèmes nationaux d'innovation à l'ère de la globalisation. Paris: Economica.

Amable, B. (2005). Les cinq capitalismes. Paris: Seuil.

Antonelli, C. (2003). The Economics of Innovation, New Technologies, and Structural Change. London: Routledge.

Aréna, R., \& Lazaric, N. (2003). La théorie évolutionniste du changement économique de Nelson et Winter. Revue économique, 54(2), 329-354. https://doi.org/10.2307/3503006

Arkolakis, C., Ramondo, N., Clare, A. R., \& Yeaple, S. R. (2018). Innovation and production in the global economy. American Economic Review, 108(8), 2128-2173.

https://doi.org/10.1257/aer.20141743

Aydalot, P. (1984). Crise et Espace. Paris: Economica.

Aydalot, P. (1986a). Milieux Innovateurs en Europe. Paris: Gremi.

Augustine, R. N. (1997). Reshaping an Industry: Lockheed Martin's Survival Story. Harvard Business Review, 75(3), 83-94.

Bartlett, A. C., \& Ghoshal, S. (2002). Managing Across Borders: The Transnational Solution. (2nd ed.). Boston: Harvard Business Review Press.

Bassis, F. N., \& Armellini, F. (2018). System of innovation and innovation ecosystem: a literature review in search of complementaries. Journal of Evolutionary Economics, 28(5), 1053-1080. https://doi.org/10.1007/s00191-018-0600-6

Belasco, A. J., \& Stayer, C. R. (1994). Flight of the Buffalo: Soaring to Excellence, Learning to Let Employees Lead. New York: Warner Books.

Bennis, W. (2009). On Becoming a Leader. New York: Basic Books.

Bennis, W., \& Goldsmith, J. (2010). Learning to Lead: A Workbook on Becoming a Leader. New York: Basic Books.

Billaudot, B. (1996). L'ordre économique de la société moderne. Paris: L'Harmattan.

Billaudot, B. (2001). Régulation et croissance. Une macroéconomie historique et institutionnelle. Paris: L'Harmattan.

Birkinshaw, J., Hamel, G., \& Mol, M. (2008). Management innovation. Academy of Management Review, 33(4), 825-845. https://doi.org/10.5465/amr.2008.34421969

Blaug, M. (2008). "British classical economics," The New Palgrave Dictionary of Economics. (2nd ed.). Cheltenham, UK/ Northampton, USA: Edward Elgar Publishing. 
https://doi.org/10.1057/978-1-349-95121-5_99-2

Boonstra, J. J., \& Vink, M. J. (1996). Technological and organizational innovation: A dilemma of fundamental change and participation. European Journal of Work and Organizational Psychology, 5(3), 351-376. https://doi.org/10.1080/13594329608414865

Boyer, R., \& Didier, M. (1998). Relancer une dynamique de la croissance durable par l'innovation, rapport pour le Conseil d'analyse économique. Paris: La Documentation française.

Boyer, R., \& Freyssenet, M. (2000). Les Modèles productifs. Paris : La Découverte, collection Repères.

Boyer, R. (2004). Théorie de la régulation, 1. Les fondamentaux. Paris : La Découverte, collection Repères.

Bremmer, I. (2014). The New Rules of Globalization. Harvard Business Review, 92(1), 103-107.

Brynjolfsson, E., \& Mc Afee, A. (2015). Le Deuxième Âge de la machine: travail et prospérité à l'heure de la révolution technologique. Paris: Odile Jacob.

Carlino, G., \& Kerr, W. (2015). Agglomeration and innovation. In Duranton, G., Henderson, J. V., \& Strange, W (Eds.), Handbook of Regional and Urban Economics, 5A, (pp.349-404). Amsterdam: Elsevier. https://doi.org/10.1016/B978-0-444-59517-1.00006-4

Castoriades, C. (1987). The Imaginary Institution of Society. Campridge, UK/Massachusetts, USA: Polity Press.

Cerne, M., Jaklic, M., \& Skerlavaj, M. (2016). Management innovation enters the game: Re-considering the link between technological innovation and financial performance. Innovation: Organization \& Management, 17(4), 429-449.

https://doi.org/10.1080/14479338.2015.1126530

Chandler, A. D. (1990). Scale and Scope. The Dynamics of Industrial Capitalism. Cambridge, Massachusetts: Belknap Press (Harvard University Press).

Chaney, T. (2016). Networks in international trade. In Bramoullé, Y., Galeotti, A., \& Rogers, B. (Eds.), Oxford Handbook of the Economics of Networks (pp. 754-775). Oxford: Oxford University Press.

Christensen, M. C., \& Boyer, L. J. (1995). Disruptive Technologies: Catching the Wave. Harvard Business Review, 73(1), 43-53.

Christensen, M. C., \& Raynor, E. M. (2003). The Innovator's Solution: Creating and Sustaining Successful Growth. Boston: Harvard Business Review Press.

Christensen, M. C., Dillon, K., \& Hall, T. (2016). Competing Against Luck: The Story of Innovation and Customer Choice. New York: Harper Business School Press.

Clarke, T., \& Clegg, S. (2000). Changing Paradigms. London: Harper Collins. 


\section{Macrothink}

Business and Economic Research ISSN 2162-4860 2019, Vol. 9, No. 1

Clément, C. L., \& Lelarge, C. (2006). L'innovation dans l'industrie: une contribution forte à la croissance de la productivité globale. Le 4-pages, SESSI, n॰224.

Coriat, B., \& Weinstein, O. (1995). Les nouvelles théories de l'entreprise. Paris: Le Livre de Poche.

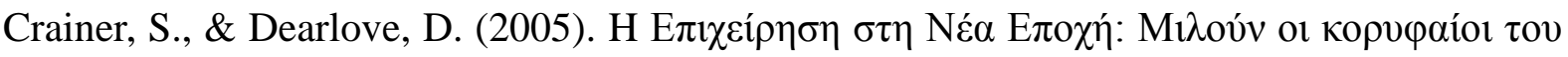

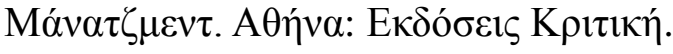

Crossan, M., \& Apaydin, M. (2009). A Multi-Dimensional Framework of Organizational Innovation: A Systematic Review of the Literature. Journal of Management Studies, 47(6), 1154-1191. https://doi.org/10.1111/j.1467-6486.2009.00880.x

Damanpour, F. (2010). An integration of research findings of effects of firm size and market competition on product and process innovations. British Journal of Management, 21(4), 996-1010. https://doi.org/10.1111/j.1467-8551.2009.00628.x

Damanpour, F. (2016). Organizational Innovation. Oxford Research Encyclopedia of Business and Management. USA: Oxford University Press.

Dasgupta, P., \& David, P. (1994). Towards a new economics of science. Research Policy, 23(5), 487-521. https://doi.org/10.1016/0048-7333(94)01002-1

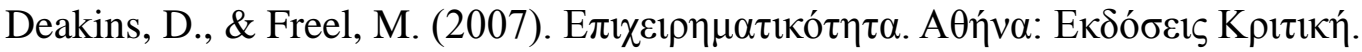

Dertouzos, L. M., Lester, K. R., \& Solow, M. R. (1989). Made In America: Regaining the Productive Edge. Cambridge: MIT Press.

Dienstag, F. J. (2006). Pessimism: Philosophy, Ethic, Spirit. New Jersey: Princeton University Press.

Dogan, M. (2001). Paradigms in the Social Sciences. In Smeltser, J. N., \& Baltes, P. B. (Eds.), International Encyclopedia of the Social and Behavioral Sciences, 16 (New-Per), (pp.11023-11027). Amsterdam: Elsevier. https://doi.org/10.1016/B0-08-043076-7/00782-8

Dosi, G., \& Nelson, R. (1994). An Introduction to Evolutionary Theories in Economics. Journal of Evolutionary Economics, 4(3), 153-172. https://doi.org/10.1007/BF01236366

Durand, R. (2000). Entreprise et évolution économique. Paris: Belin.

Edersheim, H. E. (2007). The Definitive Drucker. New York: McGraw-Hill.

Edquist, C., \& Hommen, L. (2008). Small Country Innovation System: Globalization, Change and Policy in Asia and Europe. U.K.: Edward Elgar.

https://doi.org/10.4337/9781847209993

Eisenhardt, K., \& Martin, J. A. (2000). Dynamic capabilities: What are they? Strategic Management Journal, 21, 1105-1121.

https://doi.org/10.1002/1097-0266(200010/11)21:10/11<1105::AID-SMJ133>3.0.CO;2-E

Fagerberg, J., Fosaas, M., \& Sapprasert, K. (2012). Innovation: Exploring the knowledge 
base. Research Policy, 41(7), 1132-1153. https://doi.org/10.1016/j.respol.2012.03.008

Fonseca, J. (2002). Complexity and Innovation in Organizations: Complexity and Emergence in Organizations. London: Routledge. https://doi.org/10.4324/9780203279267

Freeman, C., \& Soete, S. (1994). Work for All or Mass Unemployment? Computerized Technical change into 21 st Century. London/New York: Pinter Publishers.

Freeman, C. (1995). The 'National System of Innovation' in historical perspective. Cambridge Journal of Economics, 19(1), 5-24.

Freeman, C., \& Soete, L. (1997). The Economics of Industrial Innovation. Cambridge: MIT Press.

Freeman, C. (2002). Continental, national and sub-national innovation system-complementarity and economic growth. Research Policy, 31(2), 191-211.

https://doi.org/10.1016/S0048-7333(01)00136-6

Gabrié, H., \& Jacquier, J. L. (1994). La Théorie moderne de l'entreprise. Paris: Economica.

Geels, F. (2005). Technological Transitions and System Innovations: A Co-Evolutionary and Socio-Technical Analysis. UK: Edward Elgar. https://doi.org/10.4337/9781845424596

Ghoshal, S., \& Bartlett, A. C. (1999). The Individualized Corporation: A Fundamentally New Approach to Management. New York: Harper Business.

Gibson, R. (1998). Rethinking the Future: Rethinking Business Principles, Competition, Control and Complexity, Leadership, Markets and the World. London: Nicholas Brealey Publishing.

Godin, B. (2015). Innovation contested: The idea of innovation over the centuries. London: Routledge. https://doi.org/10.4324/9781315855608

Goleman, D. (1998). The emotional intelligence of leaders. Leader to Leader Institute, 10, 20-26. https://doi.org/10.1002/ltl.40619981008

Goleman, D. (2005). Emotional intelligence: Why it Can Matter More Than IQ. (10th ed.). New York: Batman Dell.

Gordon, R. (2016). The Rise and Fall of American Growth. New Jersey: Princeton University Press. https://doi.org/10.1515/9781400873302

Guellec D., \& Paunov, C. (2017). Digital innovation and the distribution of income (NBER Working Paper No.23987). U.S: National Bureau of Economic Research. https://doi.org/10.3386/w23987

Guillaume. H. (1998). Technologie et innovation, rapport pour le gouvernement. Paris: La Documentation Française.

Grant, R. M., \& Baden-Fuller, C. (2004). A knowledge accessing theory of strategic alliances. Journal of Management Studies, 41(1), 61-84. 
https://doi.org/10.1111/j.1467-6486.2004.00421.x

Hamel, G. (2000). Leading The Revolution. USA: Penguin Books.

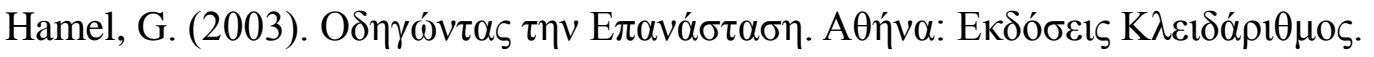

Hamel, G. (2006). The why, what and how of management innovation. Harvard Business Review, 84(2), 72-84.

Hammer, M., \& Champy, J. A. (1993). Reengineering the Corporation: A Manifesto for Business Revolution. New York: Harper Business Books.

https://doi.org/10.1016/S0007-6813(05)80064-3

Hanson, G., Lind, N., \& Muendler, M. (2015). The dynamics of comparative advantage. (NBER Working Paper No. 21753). U.S: National Bureau of Economic Research. https://doi.org/10.3386/w21753

Hayek, A. F. (1941). The Pure Theory of Capital. Chicago: University of Chicago Press.

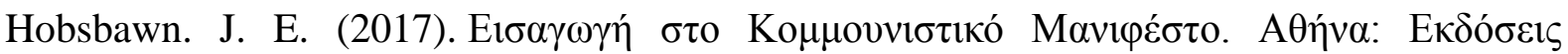
$\Pi \lambda \dot{\varepsilon} \theta \rho o v$.

Howe, J. (2009). Crowdsourcing: Why the Power of the Crowd Is Driving the Future of Business. U.S: Crown Business.

Kanter, M. S. (2006). Confidence: How Winning Streaks and Losing Streaks Begin and End. U.S: Crown Business.

Kanter, M. S. (2009). SuperCorp: How Vanguard Companies Create Innovation, Profits, Growth, and Social Good. U.S: Crown Business.

Kashan, J. A., \& Mohannak, K. (2017). The Role of Knowledge Integration in Capability Development and Emergence of Innovation Ecosystem. International Journal of Innovation and Technology Management, 14(5). https://doi.org/10.1142/S0219877017500274

Katimertzopoulos, F., \& Vlados, C. M. (2017). Local support mechanisms for entrepreneurship: The approach of local development and innovation institutions. International Journal of Business and Economic Sciences Applied Research, 10(1), 30-41. https://doi.org/10.25103/ijbesar.101.04

Kauffman, A. S. (1993). The Origins of Order: Self-Organization and Selection in Evolution. New York: Oxford University Press.

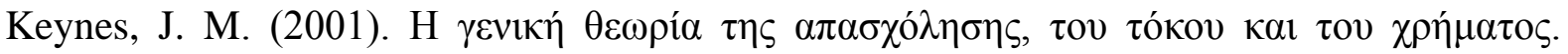

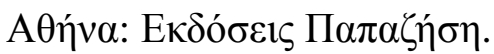

Kim, C. W., \& Mauborgne, R. (2005). Blue Ocean Strategy: How to Create Uncontested Market Space and Make Competition Irrelevant. Boston: Harvard Business Review Press.

Krugman, P. (1990). Rethinking International Trade. Cambridge: MIT Press.

https://doi.org/10.7551/mitpress/5933.001.0001 
Krugman, P. (2014, June 16). Creative Destruction Yada Yada. The New York Times.

Kuhn, S .T. (2012). The Structure of Scientific Revolutions. 50th anniversary. (4th ed.). Chicago: University of Chicago Press.

https://doi.org/10.7208/chicago/9780226458144.001.0001

Leadbeater, C. (2009). We-Think: Mass innovation, not mass production. UK: Profile Books.

Lebas, C. (2003). La théorie évolutionniste de la firme; état des lieux raisonné et implications pour l'analyse stratégique. WP, centre Walras, université Lyon 2. Cambridge : Cambridge University Press.

Lepore, J. (2014, June 23). Annals of enterprise: The disruption machine: What the gospel of innovation gets wrong. The New Yorker.

Li, Y., Lee, S., Li, X., \& Liu, Y. (2010). Knowledge codification, exploitation, and innovation: The moderating influence of organizational controls in Chinese firms. Management and Organization Review, 6(2), 219-241. https://doi.org/10.1111/j.1740-8784.2010.00179.x

Marin, A., Navas-Aleman, L., \& Perez, C. (2015). Natural Resource Industries as a Platform for the Development of Knowledge Intensive Industries, Tijdschrift voor economische en sociale geografie. Journal of Economic and Social Geography, 106(2), 154-168.

Markides, C. C., \& Geroski, A. P. (2004). Fast Second: How Smart Companies Bypass Radical Innovation to Enter and Dominate New Markets. USA: Jossey-Bass.

Markides, C. C. (2008). Game-Changing Strategies: How to Create New Market Space in Established Industries by Breaking the Rules. USA: Jossey-Bass.

Marshall, A. (1890). Principles of Economics. (1st ed.). London: Macmillan.

Marx, K. (1955). The Poverty of Philosophy. Moscow: Progress Publishers.

Marx, K. (1976). Das Kapital, Harmondsworth. USA: Penguin Books.

Maurice, M., \& Sorge, M. (2000). Embedding Organizations. Amsterdam/Philadelphie: John Benjamin's Publishing Company. https://doi.org/10.1075/aios.4

Menard, C. (1994). L'Economie des Organisations. Paris, La Decouverte.

Metcalfe, S., \& Georghiou, L. (1997). Equilibrium and Evolutionary Foundations of Technology Policy. (CRIC Discussion Paper No 3). Centre for Research on Innovation and Competition. Manchester: University of Manchester.

Narayanan, V. K. (2000). Managing Technology and Innovation for Competitive Advantage. London: Pearson.

Narayanan, V. K., \& O'Connor, C. G. (2010). Encyclopedia of Technology and Innovation Management. New Jersey: Wiley-Blackwell.

Nonaka, I., \& Konno, N. (1998). The concept of Ba: Building for knowledge creation. California Management Review, 40(3), 40-54. https://doi.org/10.2307/41165942 
OECD, (1997). National Innovation Systems. Paris: OECD Publications.

OCDE, (2014a). Examens des politiques d'innovation. Paris: OECD Publications.

OCDE, (2014b). New sources of growth: knowledge-based capital. Paris: OECD Publications.

OCDE, (2016). Science, technology and innovation outlook. Paris: OECD Publications. https://doi.org/10.1787/sti_in_outlook-2016-en

Parkin, M. (1997). Microeconomics. (4th ed.). Boston: Addison Wesley.

Patel, P., \& Pavitt, K. (1994). The Nature and Economic Importance of National Innovation Systems. STI Review, OECD, 14, 9-32.

Paunov, C. (2012). The global crisis and firms' investments in innovation. Directorate for Science, Technology and Industry, OECD, 41(1), 24-35.

https://doi.org/10.1016/j.respol.2011.07.007

Perez, C. (1983). Structural change and assimilation of new technologies in the economic and social systems. Futures, 15(5), 357-375. https://doi.org/10.1016/0016-3287(83)90050-2

Perez, C. (2013). Unleashing a golden age after the financial collapse: Drawing lessons from history. Environmental Innovations and Societal Transitions, 80(1), 11-23.

https://doi.org/10.1016/j.eist.2012.12.004

Pérez, R. (2003). La Gouvernance de l'entreprise, La Découverte. Paris : Collection Repères.

Porter, M. E. (1990). The Competitive Advantage of Nations. Harvard Business Review, 68(2), 73-93. https://doi.org/10.1007/978-1-349-11336-1

Porter, M. E. (1996). What is a strategy?. Harvard Business Review, 74(6), 61-78.

Porter, M. E., \& Heppelmann, J. E. (2014). How Smart, Connected Products are Transforming Competition. Harvard Business Review, 92(11), 64-88.

Porter, M. E., \& Heppelmann, J. E. (2015) How Smart, Connected Products are Transforming Companies. Harvard Business Review, 93(10), 96-112.

Prahalad, C. K. (2004). The Future of Competition: Co-Creating Unique Value. Boston: Harvard Business School Press.

Prax, J. Y. (2007). Le manuel du knowledge management. ( $2^{\mathrm{e}}$ éd.). Paris: Dunod.

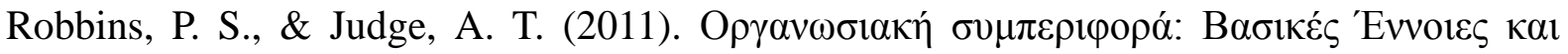

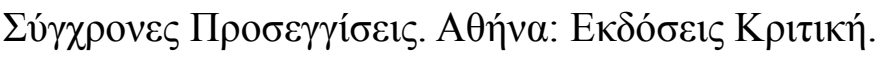

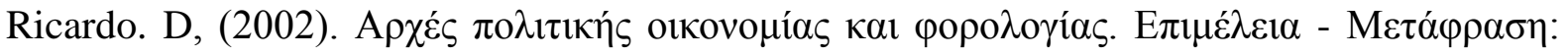

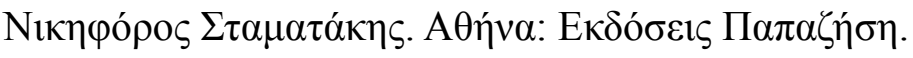

Ridderstråle, J., \& Wilcox, M. (2009). Re-energizing the Corporation: How Leaders Make Change Happen. New Jersey: John Wiley \& Sons. 
Rinkinen, S., \& Harmaakorpi, V. (2018). The business ecosystem concept in innovation policy context: building a conceptual framework. Innovation: The European Journal of Social Science Research, 31(3), 333-349. https://doi.org/10.1080/13511610.2017.1300089

Sako, M. (2018). Business ecosystem: how do they matter for innovation?. Communications of the ACM, 61(4), 20-22. https://doi.org/10.1145/3185780

Scherer, F. M. (1984). Innovation and Growth. Schumpeterian Perspectives. Cambridge, MA: MIT Press.

Schilling, M. A. (2008). Strategic management of technological innovation. New York: McGraw-Hill Irwin.

Screpanti, E., \& Zamagni, S. (2005). An Outline of the History of Economic Thought. New York: Oxford University Press. https://doi.org/10.1093/0199279144.001.0001

Shacle, G.L.S. (1967). The Years of High Theory. London: Cambridge University Press.

Simon, H. (1982). Models of Bounded Rationality. Cambridge, MA: The M.I.T Press.

Skousen, M. A. (2008). Classical Economics. In Hamowy, Ronald. (Eds.), The Encyclopedia of Libertarianism (pp.71-73). Thousand Oaks, CA: SAGE.

https://doi.org/10.4135/9781412965811.n47

Slaboch, W. M. (2018). A Road to Nowhere: The Idea of Progress and Its Critics. USA: The University of Pennsylvania.

Smith, A. (2000). The Wealth of Nations / Adam Smith; introduction by Robert Reich; edited, with notes, marginal summary, and enlarged index by Edwin Cannan. New York: Modern Library.

Schumpeter, A. J. (1942). Capitalism, socialism and democracy. United States: Harper \& Brothers.

Schumpeter, A. J. (1949). Historical Approach to the Analysis of Business Cycles. In National Bureau of Economic Research (NBER). Proceedings of the Conference on Business Cycle Research. US: NBER.

Schumpeter, A. J. (1951). Ten great economists: from Marx to Keynes. New York: Oxford University Press.

Tapscott, D., \& Williams, D. A. (2010). Wikinomics: How Mass Collaboration Changes Everything. USA: Portfolio.

Uchupalanan, K. (2000). Competition and information technology-based innovation in banking services. International Journal of Innovation Management, 4(4), 455-489. https://doi.org/10.1142/S1363919600000238

Veltz, P. (2000). Le Nouveau Monde industriel. Paris: Gallimard.

Vlados, Ch., \& Katimertzopoulos, F. (2018). Assessing Meso and Micro-Competitiveness 
Boosting Policies, in Stra.Tech.Man Terms. International Journal of Business and Social Research, 8(9), 1-15.

Volberda, H. W., Van Den Bosch, F. A., \& Mihalache, O. R. (2014). Advancing management innovation: Synthesizing processes, levels of analysis, and change agents. Organization Studies, 35(9), 1245-1264. https://doi.org/10.1177/0170840614546155

Walker, R. M., Damanpour, F., \& Devece, C. A. (2011). Management innovation and organizational performance: Mediating role of planning and control. Journal of Public Administration Research and Theory, 21(2), 367-386. https://doi.org/10.1093/jopart/muq043

Walker, R., Chen, J., \& Aravind, D. (2015). Management innovation and firm performance: An integration of research findings. European Management Journal, 33(5), 407-422. https://doi.org/10.1016/j.emj.2015.07.001

Walras, L. (2010). Elements of Pure Economics. (Paperback 1st ed.). London: Routledge.

Weeks, M. (2015). Is disruption theory wearing new clothes or just naked? Analyzing recent critiques of disruptive innovation theory. Innovation, 17(4), 417-428.

https://doi.org/10.1080/14479338.2015.1061896

White, H. C. (2002). Markets from Networks: Socioeconomic Models of Production. New Jersey: Princeton.

Williamson, O. E., \& Winter, G. S. (1991). The Nature of the Firm: Origins Evolution and Development. New York: Oxford University Press.

Weinberger, J. (1976). Science and Rule in Bacon's Utopia: An Introduction to the Reading of the New Atlantis. The American Political Science Review, 70(3), 865-885.

https://doi.org/10.2307/1959872

Weintraub, R. E. (2007). Neoclassical Economics. The Concise Encyclopedia of Economics. Indiana, USA: Library of Economics and Liberty.

Wolfe, R. (1994). Organizational Innovation: Review, Critique, and Suggested Research Directions. Journal of Management Studies, 31(26), 405-431.

https://doi.org/10.1111/j.1467-6486.1994.tb00624.x

Wolfe, R., Wright, P., \& Smart, D. (2006). Radical HRM Innovation and Competitive Advantage: The Moneyball Story. Human Resource Management Journal, 45(1), 111-145. https://doi.org/10.1002/hrm.20100

Wooldridge, A., \& Micklethwait, J. (2011). The Right Nation: Why America is Different. U.K: Penguin.

Zhou, M., \& Sun, Y. (2016). Editorial - Strategy and Execution of Innovation and Entrepreneurship. International Journal of Innovation and Technology Management, 13(3). https://doi.org/10.1142/S0219877016020016

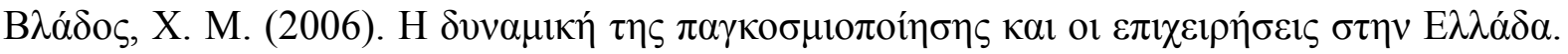




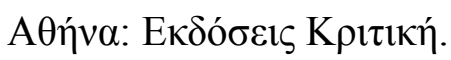

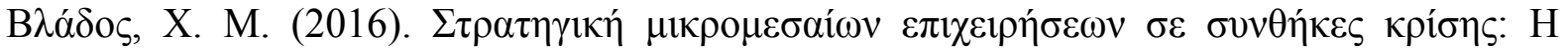

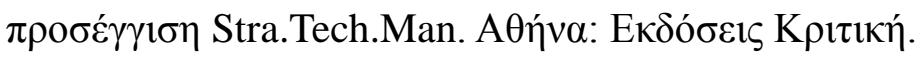

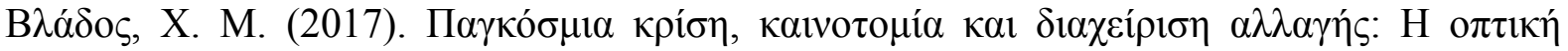

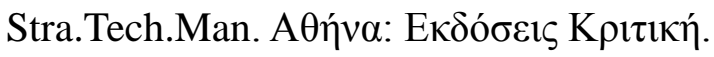

\section{Notes}

Note 1. What is, for Michael Porter, the role of technology in this increasingly fast global innovation race?

In simple terms, purely scientific innovations are not particularly important: on the contrary, an important source of advantage is the ability to apply technology. And for technology to be applied it should be able to be connected with a variety things. Ultimately, in the markets those who can understand how to integrate technology into the wider system of the company can be successful (Porter, 1996).

Note 2. Obviously, it is clear that the "blue ocean" approach comes in significant contrast to the conventional theory of sectoral strategy: Both the "traditional" model of Porter's five forces-which helps businesses determine how they can compete with the in the best possible way in an existing market-sector, and the logic of re-designing Hammer's business operations.

Note 3. Of course things are never so simple. According to Constantinos Markides, for example, very often, a "fast second" business lets the "leading" companies innovate and experiment, creating new markets in their first steps. Leaving them to bear the burden of the great uncertainty of "start-up", "first customers training" costs and the huge operability costs of the idea, the "fast second" enter the markets, as soon as the "dominant model" in the new market tends to emerge, to clear, to consolidate and to prevail, utilizing its largest size, greater awareness, wider networks and great overall business experience.

Note 4. Namely with the Solution of innovation, Christensen \& Raynor (2003) are demonstrating, in fact, to companies how to create inversions instead of destroying them, without giving however any concrete solution or a clear strategic path towards innovation.

Note 5. In a converging perspective, Daniel Goleman (1998; 2005) analysis of "emotional intelligence" is based on the idea that the ability of managers to understand and control their own feelings and relationships is the key to a better innovation performance.

\section{Copyright Disclaimer}

Copyright for this article is retained by the author(s), with first publication rights granted to the journal.

This is an open-access article distributed under the terms and conditions of the Creative Commons Attribution license (http://creativecommons.org/licenses/by/3.0/). 